\title{
Fluoride Varnishes in Caries Prevention
}

\author{
Liisa Seppä \\ Institute of Dentistry, University of Oulu, Oulu, Finland
}

\section{Key Words}

Dental caries · Fluoride varnish · Prevention

\begin{abstract}
The first fluoride varnishes were developed during the 1960s (Duraphat ${ }^{\circledR}$ sodium fluoride varnish) and 1970s (Fluor Protector ${ }^{\circledR}$ silane fluoride varnish) to prolong the contact time between fluoride and enamel. Fluoride varnishes adhere to enamel, and calcium fluoride formed after application acts as a long-term reservoir of fluoride. Currently Duraphat varnish is the most widely used topical fluoride for professional application in Europe, and the use of fluoride varnishes is increasing in the USA. Duraphat varnish has been effective in three decades of clinical studies, but the results of Fluor Protector varnish are inconclusive. The percent caries reductions found in the 1990s have generally been lower than those reported in earlier studies, probably because of the higher exposure to other preventive measures in the more recent studies. In studies comparing Duraphat varnish and APF gel, Duraphat varnish was equally or more effective than APF gel. Sealants were most effective in preventing occlusal caries. Four applications per year, or three weekly applications once a year, have been found to be effective. However, several studies have shown that two applications per year may provide comparable results. Application is fast and easy. Professional prophylaxis is not necessary, and the patient can leave immediately after the treatment. No acute toxicity has been reported after using any fluoride varnish.
\end{abstract}

Copyright @ 2004 S. Karger AG, Basel

\begin{tabular}{ll}
\hline KARGER & ( ) 2004 S. Karger AG, Basel \\
1011-7571/04/0136-0307\$21.00/0 \\
$\begin{array}{l}\text { Fax +41 61306 1234 } \\
\text { E-Mail karger@karger.ch } \\
\text { www.karger.com }\end{array}$ & $\begin{array}{l}\text { Accessible online at: } \\
\text { www.karger.com/mpp }\end{array}$
\end{tabular}

\section{Development of Fluoride Varnishes and Their Mechanism of Action}

In the 1940 s, a sodium fluoride $(\mathrm{NaF})$ solution for topical application on teeth was introduced to provide fluoride to individuals in non-fluoridated areas [1, 2]. During the following decades, professional application of fluoride solutions and gels gradually became a common caries-preventive measure. Observations of elevated fluoride concentration in enamel after application of topical fluorides stimulated the development of techniques for permanent fixation of fluoride in the form of fluorapatite in enamel. In 1964, Schmidt [3] presented a method of applying $\mathrm{NaF}$ in a natural colophony base, which could adhere to tooth surfaces in the presence of saliva. This product was further developed and registered as Duraphat ${ }^{\circledR}$ (now produced for Colgate Oral Pharmaceuticals by Natterman \& Cie, GmbH, Köln, Germany). A varnish consisting of silane fluoride in a polyurethane polymer was introduced in the 1970s (Fluor Protector ${ }^{\circledR}$, Ivoclar Vivadent, Schaan, Liechtenstein). The varnishes were originally developed to prolong the contact time between fluoride and tooth enamel.

Application of varnish on tooth surfaces was shown to promote the uptake of firmly bound fluoride by enamel, which was considered important at that time [4-7]. However, the concept of the cariostatic mechanism of fluoride has changed considerably over the past few decades. In addition to fluoride incorporation into the crystalline lattice, fluoride varnishes and other concentrated topical fluorides interact with saliva and form calcium fluoride

Liisa Seppä

Institute of Dentistry, University of Oulu

POB 5281

FI-90014 Oulu (Finland)

Tel. +358 85375577 , Fax +358 85375560 , E-Mail liisa.seppa@oulu.fi 
$\left(\mathrm{CaF}_{2}\right)$ compounds on enamel. The formation of $\mathrm{CaF}_{2}$ has long been assumed to be an unwanted side-reaction because it was thought to dissolve easily from the enamel soon after application. Nevertheless, according to studies from the 1980s [8-10], $\mathrm{CaF}_{2}$ is stabilized by pellicle proteins and secondary phosphate at neutral $\mathrm{pH}$. When the $\mathrm{pH}$ of plaque drops, $\mathrm{CaF}_{2}$ begins to dissolve and release fluoride ions, thus acting as a prolonged source of fluoride after application [8-10]. Today, this is considered the most important factor in caries prevention for concentrated topical fluorides, including fluoride varnishes [11].

\section{Early Studies of the Efficacy of Fluoride Varnishes}

The first studies of fluoride varnishes compared fluoride varnish treatment with a control group receiving no treatment. In 1968, Heuser and Schmidt [12] published a clinical study using one yearly application of Duraphat $\mathrm{NaF}$ varnish (Golgate Oral Pharmaceuticals 2.26\% fluoride) in children. They showed significant caries reduction ranging from 27 to $49 \%$ in different subgroups; the mean reduction was $36 \%$. In a 1 -year study by Koch and Petersson [13] exceptionally good results were reported, whereby semi-annual applications of Duraphat varnish reduced caries by $75 \%$. In 1979, Holm [14] reported DMFS reduction of $44 \%$ in 3-year-old children. In the same year, Salem et al. [15] first published a study where Fluor Protector silane fluoride varnish proved effective. At that time Fluor Protector varnish contained 0.7\% fluoride, but the concentration was later reduced to $0.1 \%$.

The first clinical study comparing Duraphat and Fluor Protector varnishes was conducted in high-caries-risk children in an area with fluoridated water [16]. The halfmouth technique was used, which probably diminished the observed caries-preventive effect. Despite this limitation, Duraphat varnish achieved a caries reduction of $30 \%$, but the caries reduction by Fluor Protector varnish was not significant, probably because fluoride from Fluor Protector had moved to the control side of the mouth. Fluor Protector varnish deposited significantly more fluoride in the enamel than Duraphat varnish, a finding which has also been reported in other studies [17-19]. The reason for this finding is unclear. Nevertheless, Fluor Protector varnish has never been clinically proven to be more effective than Duraphat varnish, which further suggests that firmly bound fluoride is not the main mechanism of caries prevention by fluoride varnishes.
In 1985, Clark et al. [20] published a study comparing Durafluor ${ }^{\circledR}$ varnish (Pharmascience Inc., identical to Duraphat) and Fluor Protector varnish. Caries reduction of $22 \%$ was reported for Durafluor varnish and 17\% for Fluor Protector varnish in 6- to 7-year-old children. The positive results of these early studies promoted the use of Duraphat varnish in Scandinavia in the early 1980s.

\section{Later Studies}

Over the past two decades, numerous clinical studies of fluoride varnishes, especially Duraphat varnish, have been conducted. In the majority of studies, Duraphat varnish has produced significant caries reduction or inhibited progression of caries in both primary and permanent teeth [21-24]. The vast majority of studies has been conducted in children and adolescents. Fluor Protector varnish has produced significant caries reduction in preschool children in one study [25]. A varnish containing $\mathrm{NaF}$ and $\mathrm{CaF}_{2}\left(\right.$ Bifluorid $^{\circledR}$, VOCO $\left.\mathrm{GmbH}\right)$ is marketed for hypersensitive teeth and caries prevention, but its cariostatic effect was established in only one clinical study [26]. In general, the percentage of caries reduction found in the studies conducted in the 1990s was lower than the results reported in earlier studies. This difference was probably the result of concomitant high exposure to other preventive measures in countries where the studies were conducted. The effect of fluoride varnishes as well as other preventive measures is greatly influenced by circumstances under which they are applied. For instance, in a clinical trial conducted in Finland, no caries reduction in high-caries-risk children was observed despite the highly intensive preventive programme including fluoride varnish applications [27].

\section{Reviews and Meta-Analyses}

Several reviews of studies using fluoride varnishes have been published [28-33]. In most of them, evidence for the efficacy of Duraphat varnish has been considered to be well established. In the meta-analysis by Helfenstein and Steiner [34], the results of 8 studies of Duraphat varnish were included. Overall reduction was 38\% (95\% CI 19-57\%), but the authors suggested that because of publication bias, the lower limit of the confidence interval was probably closer to reality than the upper limit was. In a recent meta-analysis by Marinho et al. [35], the selection criteria allowed for inclusion of seven studies in the analy- 
sis, representing approximately one fourth of the available studies. The primary measure of effect was the preventive fraction, which is the difference in caries increments between the treatment and control groups expressed as a percentage of the increment in the control group (percent caries reduction). The pooled preventive fraction estimate for DMFS was 46\% (95\% CI 30-60\%, $\mathrm{p}<0.0001$ ), and the respective estimate for DMFS was $33 \%$ (95\% CI 19-48\%, $\mathrm{p}<0.0001)$. The authors concluded that Duraphat varnish had a substantial caries-preventive effect in both the permanent and primary dentition. However, it is noteworthy that most of the studies included were conducted in the 70s and 80 s, which probably led to higher estimates of the preventive effect than would have occurred if more recent studies were included. The authors indicated a need for further clinical studies of high quality, including assessment of any potential adverse effects.

\section{Fluoride Varnish versus Acidulated Phosphate Fluoride (APF) Gel}

Although fluoride varnish has long been the most widely used professionally applied fluoride preparation in North and Central Europe, APF gel is still commonly used in many countries, including the USA. In 1987 Shobha et al. [36] compared Duraphat varnish to APF gel using a separate control group. Both the APF gel and fluoride varnish prevented caries significantly, but Duraphat varnish was significantly more effective than APF gel (50 vs. $30 \%$ caries reduction). In a study by Tewari et al. [37], Duraphat varnish was significantly more effective compared to $2 \% \mathrm{NaF}$ gel and APF gel, with caries reductions of $26 \%$ for NaF gel, $35 \%$ for APF gel and $74 \%$ for Duraphat varnish. In a study by Seppä et al. [38] comparing Duraphat varnish and APF gel (Nupro ${ }^{\circledR}$ ) without a separate control group, no significant difference in caries increment between the two groups was reported, and the children accepted both procedures well. The application time for APF gel was about 6 min compared with $2 \mathrm{~min}$ for the Duraphat varnish.

\section{Fluoride Varnish versus Sealants}

Bravo et al. [39] compared the effect of sealants (Delton ${ }^{\circledR}$ ) to Duraphat applications every 6 months in newly erupted first molars. The study included a separate control group that received no treatment. Both the sealants and fluoride varnish were effective in preventing caries, but sealants were significantly more effective than varnish. Florio et al. [40] compared the efficacy of resin-modified glass-ionomer (Vitremer ${ }^{\circledR}$ ) used as a sealant, Duraphat varnish for tooth brushing plus weekly mouthrinsing for treatment of active incipient caries on occlusal surfaces of first molars. Also in this study, sealants were significantly more effective in arresting caries than the other two methods.

\section{Technique and Frequency of Varnish Application}

Varnish manufacturers recommend professional cleaning of teeth before application of the product. However, professional prophylaxis is time-consuming, and there is no scientific evidence of any benefit of this procedure. In a clinical study by Seppä [41] uptake of fluoride by enamel from Duraphat application was not significantly different in teeth with and without prior prophylaxis. The results of this study suggested that removal of plaque is not necessary. It is not necessary for teeth to be thoroughly dry before application; light blowing of air on teeth or wiping them with a cotton roll is sufficient. The varnish is applied on tooth surfaces where caries usually develops by using a brush or applicator. The varnish adheres to the tooth surface, and the patient can leave immediately after application. Brushing has to be avoided for the remainder of the day. The manufacturer suggests avoiding eating for 2-4 $\mathrm{h}$ after application.

Originally, semi-annual applications of the varnish were recommended. This frequency has mostly been used in the varnish studies and also in practice. It has been suggested that increasing the frequency of application might increase the efficacy of the varnishes. However, there is no clear evidence of improved efficacy. In the studies by Seppä and Tolonen [42] and Osvik et al. [43] four applications of Duraphat were not more effective than two yearly applications. Fluoride varnishes must be reapplied regularly because their effect gradually disappears when the applications are stopped [44].

In 1994, Petersson and Westerberg [45] presented the results of a new system for varnish application. Once a year, they applied Duraphat varnish three times a week in 11-year-old children and compared this regimen to the traditional semi-annual applications. The study duration was 3 years. After 7 years, the group receiving intensified treatment, referred to as the new treatment regimen, had $37 \%$ less DMFS when compared to the other group. In 
1994, Sköld et al. [46] confirmed these results with the exception that their control group received only one yearly application. The theoretical basis for the superiority of this regimen is unclear. However, this system is now used in many places in Sweden, while in Finland, semi-annual applications are commonly used for persons with high caries activity.

\section{Safety of Varnish Applications}

Duraphat varnish is one of the most concentrated commercial fluoride products available in Europe, containing almost twice as much fluoride as APF gels. However, this varnish does not appear to cause health problems, even in young children. Roberts and Longhurst [47] reported that the mean amount of varnish used when applying Duraphat varnish for children aged 2-14 years was $5.2 \mathrm{mg}$ (range $0.7-14.5 \mathrm{mg}$ ). None of the children received fluoride amounts that could cause acute toxicity. Ekstrand et al. $[48,49]$ have shown that in young children the plasma fluoride peak after Duraphat application is only one seventh of the peak after application of $1.2 \%$ APF gel. This observation is probably partly the result of the more precise application technique as well as the ability of the varnish to adhere to the tooth surface, whereby it is swallowed gradually. Furthermore, some of the fluoride may not be absorbed and passes through the body. These results suggest that despite the high fluoride concentration of Duraphat, fluoride application is safe for children. Also the long period of use in Europe with no known cases or reports of acute toxicity supports this assertion [50]. Nevertheless, fluoride varnish should be applied in a thin layer and only on tooth surfaces where caries usually develops. When applied sparsely, accidental swallowing of large amounts of fluoride varnish can be avoided. Contact allergic reactions related to the colophony component of Duraphat varnish are possible [51], but rare.

\section{Current Status of Fluoride Varnishes}

In Europe and in Canada, fluoride varnishes are widely used both for children and adults. In the United States, Duraphat varnish was approved in 1994 by the US Food and Drug Administration as a medical device to be used as a cavity liner and for the treatment of hypersensitive teeth, for which purpose it is rarely used in Europe. Fluor Protector and Duraflor varnishes are also currently available in the USA. Although they are not yet approved as anticaries agents, they are mainly used for caries prevention. The use of fluoride varnishes is increasing and clinical trials are being conducted in the USA.

\section{Conclusions}

Two fluoride varnishes, Duraphat and Fluor Protector, have been used in Europe for over two decades. The $\mathrm{NaF}$ varnish Duraphat is effective in caries prevention in children and adolescents. However, the high percentage of caries reduction reported in early studies is not obtainable today because the population is also exposed to fluoride from toothpastes and other preventive measures. The results of the silane fluoride varnish Fluor Protector are more inconclusive, with some studies showing efficacy and others not. The popularity of Duraphat varnish in Europe is related to the easy and rapid application technique. The use of fluoride varnishes appears safe also for young children.

\section{References}

1 Bibby BG: The effect of sodium fluoride applications on dental caries. J Dent Res 1943;22: 207.

$\checkmark 2$ Knutson W, Armstrong WD: The effect of topically applied sodium fluoride on dental caries experience. Public Health Rep 1943;58:17011715.

3 Schmidt HFM: Ein neues Tauchierungsmittel mit besonders lang anhaltendem intensivem Fluoridierungseffekt. Stoma 1964;17:14-20.

$\checkmark 4$ Koch G, Petersson LG: Fluoride content of enamel surface treated with a varnish containing sodium fluoride. Odontol Revy 1972;23: 437-446.
5 Stamm JW: Fluoride uptake from topical sodium fluoride varnish measured by an in vivo enamel biopsy. J Can Dent Assoc 1974;7:501505.

$\checkmark 6$ Arends J, Schuthof J: Fluoride content in human enamel after fluoride application and washing: An in vitro study. Caries Res 1975;9: 363-372.

7 Seppä L, Luoma H, Hausen H: Fluoride content in enamel after repeated applications of fluoride varnishes in a community with fluoridated water. Caries Res 1982;16:7-11.

8 Fejerskov O, Thylstrup A, Larsen MJ: Rational use of fluorides in caries prevention. Acta Odontol Scand 1981;39:241-249.
-9 Øgaard B, Rølla G, Helgeland K: Fluoride retention in sound and demineralised enamel in vivo after treatment with a fluoride varnish (Duraphat). Scand J Dent Res 1984;92:190197.

10 Rølla G: On the role of calcium fluoride in the cariostatic mechanism of fluoride. Acta Odontol Scand 1988;46:341-345.

11 Øgaard B, Seppä L, Rølla G: Professional topical fluoride applications: Clinical efficacy and mechanism of action. Adv Dent Res 1994;8: 190-201.

12 Heuser H, Schmidt HFM: Zahnkariesprophylaxe durch Tiefimprägnierung des Zahnschmelzes mit Fluor-Lack. Stoma 1968;21:91100. 
13 Koch G, Petersson LG: Caries preventive effect of a fluoride-containing varnish (Duraphat ${ }^{\circledR}$ ) after 1 year's study. Community Dent Oral Epidemiol 1975;3:262-266.

14 Holm A-K: Effect of fluoride varnish (Duraphat $\left.{ }^{\circledR}\right)$ in preschool children. Community Dent Oral Epidemiol 1979;7:241-245.

15 Salem VL, Raschio JA, Reatequi JT, Montoya $\mathrm{CV}$ : Klinische Untersuchung über die karieshemmende Langzeitswirkung des Fluor-Protector-Lackes. Kariesprophylaxe 1979;1:145 148.

16 Seppä L, Tuutti H, Luoma H: Three-year report on caries prevention using fluoride varnishes for caries risk children in a community with fluoridated water. Scand J Dent Res 1982; 90:89-94.

17 Seppä L: Fluoride content of enamel during treatment and 2 years after discontinuation of treatment with fluoride varnishes. Caries Res 1984;18:278-281.

-18 Retief DH, Sorvas PG, Bradley EL, Taylor RE, Walker AR: In vitro fluoride uptake, distribution and retention by human enamel after 1and 24-hour application of various topical fluoride agents. J Dent Res 1980;59:573-588.

19 Dijkman AG, de Boer P, Arends J: In vivo investigation on the fluoride content in and on human enamel after topical application. Caries Res 1983;17:392-402.

-20 Clark CD, Stamm JW, Robert G, Tessier C: Results of a 32-month fluoride varnish study in Sherbrooke and Lac-Megantica, Canada. J Am Dent Assoc 1985;111:949-953.

-21 Frostell G, Birkhed D, Edwardsson S, Goldberg P, Petersson LG, Priwe C, Winholt AS Effect of partial substitution of invert sugar for sucrose in combination with Duraphat treatment on caries development in preschool children: The Malmo study. Caries Res 1991;25: 304-310.

\22 Peyron M, Matsson L, Birkhed D: Progression of approximal caries in primary molars and the effect of Duraphat treatment. Scand J Dent Res 1992;100:314-318.

-23 Zimmer S, Robke FJ, Roulet J-F: Caries prevention with fluoride varnish in a socially deprived community. Community Dent Oral Epidemiol 1999;27:103-108.

24 Autio-Gold J, Courts F: Assessing the effect of fluoride varnish on early enamel carious lesions in the primary dentition. J Am Dent Assoc 2001;132:1247-1253.
25 Petersson LG, Twetman S, Pakhomov GN: The efficiency of semiannual silane fluoride varnish applications: A two-year clinical study in preschool children. J Public Health Dent 1998;58:57-60.

26 Borutta A, Künzel W, Rubsam F: Kariesprotektive Wirksamkeit zweier Fluoridlacke in einer klinisch kontrollierten Zweijahresstudie. Dtsch Zahn Mund Kieferheilkd Zentralbl 1991;79:543-549.

27 Hausen H, Kärkkäinen S, Seppä L: Application of high risk strategy in controlling dental caries. Community Dent Oral Epidemiol 2000;28:2634.

28 Clark CD: A review on fluoride varnishes: An alternative topical fluoride treatment. Community Dent Oral Epidemiol 1982;10:117-123.

29 De Bruyn H, Arends J: Fluoride varnishes: A review. J Biol Buccale 1987;15:71-82.

30 Petersson LG: Fluoride mouthrinses and fluoride varnishes. Caries Res 1993;27(suppl 1):35-42.

31 Seppä L: Efficacy and safety of fluoride varnishes. Compend Contin Educ Dent 1999; (suppl 1)20:18-26.

32 Bawden JW: Fluoride varnish: A useful new tool for public health dentistry. J Publ Health Dent 1998;58:266-269.

33 Beltran-Aguilar ED, Goldstein JW, Lockwood SA: Fluoride varnishes: A review of their clinical use, cariostatic mechanism, efficacy and safety. J Am Dent Assoc 2000;131:589-596.

34 Helfenstein U, Steiner M: Fluoride varnishes (Duraphat): A meta-analysis. Community Dent Oral Epidemiol 1994;22:1-5.

35 Marinho VCC, Higgins JPT, Logan S, Sheiham A: Fluoride varnishes for preventing dental caries in children and adolescents (review); in The Cochrane Library, issue 2. Oxford, Update Software, 2003.

-36 Shobha T, Nandlal B, Prabhakar AR, Sudha P: Fluoride varnish versus acidulated phosphate fluoride for school children in Manibal. J Indian Dent Assoc 1987;59:157-160.

37 Tewari A, Chawla HS, Utreja A: Comparative evaluation of the role of NaF, APF and Duraphat ${ }^{\circledR}$ topical fluoride applications in the prevention of dental caries: A $2 \frac{1}{2} 2$-year study. J Indian Soc Pedo Prev Dent 1990;8:28-36.

38 Seppä L, Leppänen T, Hausen H: Fluoride varnish versus acidulated phosphate fluoride gel: A 3-year clinical trial. Caries Res 1995;29:273330.
39 Bravo M, Garcia-Anllo I, Baca P, Llodra JC: A 48-month survival analysis comparing sealant (Delton) with fluoride varnish (Duraphat) in 6to 8-year-old children. Community Dent Oral Epidemiol 1997;25:247-250.

40 Florio FM, Pereira AC, Meneghim Mde C, Ramacciato JC: Evaluation of non-invasive treatment applied to occlusal surfaces. ASDC J Dent Child 2001;68:326-331.

41 Seppä L: Effect of dental plaque on fluoride uptake by enamel from a sodium fluoride varnish in vivo. Caries Res 1983;17:71-75.

42 Seppä L, Tolonen T: Caries preventive effect of fluoride varnish applications performed two or four times a year. Scand J Dent Res 1990;98: 102-105.

43 Osvik A, Birkeland K, Nyland IJ: Gir fire årlige penslinger med Duraphat ${ }^{\circledR}$ fluorlakk bedre effekt enn to? Nor Tannlegeforen Tidende 1994; 104:4-6.

44 Seppä L, Tuutti H, Luoma H: Post-treatment effect of fluoride varnishes in children with a high prevalence of dental caries in a community with fluoridated water. J Dent Res 1984;63: 1221-1222.

45 Petersson LG, Westerberg I: Intensive fluoride varnish program in Swedish adolescents: Economic assessment of a 7-year follow-up study on proximal caries incidence. Caries Res 1994; 28:59-63.

46 Sköld L, Sundquist B, Ericsson B, Edeland C: Four-year study of caries inhibition of intensive Duraphat ${ }^{\circledR}$ application in 11- to 15 -yearold children. Community Dent Oral Epidemiol 1994;22:8-12.

47 Roberts JF, Longhurst P: A clinical estimation of the fluoride used during application of a fluoride varnish. Br Dent J 1987;162:463466.

48 Ekstrand J, Koch G, Petersson LG: Plasma fluoride concentration and urinary fluoride excretion in children following application of the fluoride varnish containing varnish Duraphat ${ }^{\circledR}$. Caries Res 1980;14:185-189.

49 Ekstrand J, Koch G, Lindgren LE, Petersson LG: Pharmacokinetics of fluoride gels in children and adults. Caries Res 1981;15:213-220.

50 Shen C, Autio-Gold J: Assessing fluoride concentration uniformity and fluoride release from three varnishes. J Am Dent Assoc 2002;133: 176-182.

51 Isaksson M, Bruze M, Björkner B, Niklasson B: Contact allergy to Duraphat. Scand J Dent Res 1993;101:49-51. 